\title{
The Representation of Terrorists in Egyptian Cinema: A Conversation Analysis of Al-Irhaby (The Terrorist)
}

\section{Marwa Abuelwafa}

Assistant Professor, College of Language and Communication (CLC), the Arab Academy for Science, Technology and Maritime Transport (AASTMT), Egypt.

\begin{abstract}
The soft power of media and film making has always had a great contribution to the shaping of the ideology of communities. The way certain groups or even concepts and ideas are represented in cinema affects how these groups or ideas are evaluated. This influential platform influences public opinion and shapes the stance of viewers to a great extent. The way terrorism and terrorists are characterized in films has shaped the minds and corrected or created misconceptions in many communities depending on the ideology adopted by the film makers. This study analyzes key scenes from an Egyptian movie entitled Al-Irhaby (The Terrorist) using Conversation Analysis, Brown and Levinson's Politeness Theory (1987) and Grice's Cooperative Principle (1975). This analysis aims to compare the main character's behavior before mingling with an ordinary middle class family to his behavior after staying with them for a certain period of time. The conversations between the characters throughout the movie unfold the stark differences in the main character's (the terrorist) personality and how he started rebelling against his old beliefs, a development brought about after his stay. Kress and van Leeuwan's (1996) theory of Visual Grammar is also employed but only in terms of the representational metafunction to analyze the visual techniques employed to trace such change.
\end{abstract}

Keywords: terrorism, conversation analysis, politeness theory, visual grammar, cooperative principle 


\section{Introduction}

Conversations are one of the most important activities that humans indulge in to ensure the success of the social interaction of their world. It is the way through which, “... people socialize and develop and sustain their relationships with each other" (Liddicoat, 2007, Pp.1). The conversations or dialogues in cinema are quite peculiar in nature. The linguistic expression of cinematic discourse plays a pivotal role in its peculiarity; it forms a series of dialogues written especially or scripted to be said in front of a camera. The scripted nature of these cinematic dialogues has been the reason why some researchers were, at a certain point, against the application of conversation analysis (CA) methods to cinematic discourse. In other words, this type of discourse is not natural language per se and is scripted for a particular purpose (Emmison, 1993; Schegloff, 1988). However, the application of CA to film dialogues helps reveal their organizational features and of course CA can serve as a valuable tool for such analysis (Chepinchikj \& Thompson, 2016). Cinematic discourse does not only refer to the verbal content, but to the multimodal characteristic of cinematic discourse, and this includes non-verbal as well as audiovisual aspects (Piazza et al., 2011). All the modes of cinematic representation are thus embedded in this term. Spoken discourse is but a single component of these modes that carry and convey meaning. This multimodal nature of cinema dialogues adds to its peculiarity as different from other types of discourse. This paper focuses on both spoken and visual components of cinematic discourse, where the dialogues of the key scenes are analyzed as well as the visual component using the representational metafunction of the theory of visual grammar. This study aims at analyzing conversations in key scenes selected from the movie Al-Irhaby with the aim of tracing the change that has taken place in the main character's behavior in a turning point of his life. This is done through employing conversation analysis, Brown and Levinson's politeness theory, Cooperative Principle and analyzing the imagery using the representational meta-function as a tool available via the multimodal theory of Kress and van Leeuwan $(1975 ; 1987 ; 1996)$.

\subsection{Research Questions}

The study poses and attempts to answer the following research questions:

- What are the conversational features that can show a development in a character's behaviour?

- What is the relation between the gaze and the success of the talk-in-interaction?

\section{Review of Literature}

\subsection{Principles of Conversation Analysis (CA)}

The core basis of the analysis of every day interaction is that "ordinary talk [talk-ininteraction] is a highly organized, socially ordered phenomenon" (Hutchby \& Wooffitt, 2008, p.11). However, CA hypothesizes that such orderliness is definitely not uniform or standardized, but is the product of the ventures of the communicative participants (Liddicoat, 2011). Generally, the talk-in-interaction is seen as an organized interactive activity. "Recipient design" is an important notion in CA which signifies that in communication and during a talk, participants design their utterances to be understood and conceived by the interlocutors and in doing so, 'a multitude of respects' are taken into consideration (Sacks et al., 1974). Talk-in-interaction is also not analyzed in isolation, but is a contextualized activity where there are participants communicating at a certain time in a certain place and in a certain manner. This has helped 
researchers arrive at a descriptive framework for the analysis of these communicative interactions (Schegloff, 1995).

\subsection{Brown and Levinson's Politeness Theory}

Politeness is seen as a system of interpersonal communication that was primarily created to facilitate the interaction between humans by mitigating any possible conflicts or confrontations (Lakoff, 1990). This definition was endorsed by Brown and Levinson (1987) with the addition of paying attention to the concept of face. The concept of face was first introduced by Goffman who defined it as something that is emotionally invested and which can be lost or increased in communication (1972). According to Brown and Levinson, the concept of face sketches out the human desire of the need to positively represent ourselves while avoiding any humiliation or embarrassment. The theory of politeness devised by Brown and Levinson in 1978 and revised in 1987, offers dimensions into the analysis of speech that would not have been available without such theory. Politeness is a deep-seated element of the human socio-communicative interaction. It reveals a lot about the human behavior and about the relationships between humans (Eshreteh $\&$ Darweesh, 2018). Certainly, "the notion of politeness and impoliteness has been one of the controversial issues and has been defined in many different ways since politeness theory was first introduced by Brown and Levinson" (Aydinoglu, 2013, pp. 473). During communication, speakers strive to maintain two facets of face. Positive face stands for our human need for approval from others. It represents the desire for our actions to be accepted, approved and may be also praised by others. Negative face stands for our claim for territories, personal space and preserves. It represents our wish that our actions are unimpeded by others and that we are given our own private space.

"Make your conversational contribution such as is required, at the stage at which it occurs, by the accepted purpose or direction of the talk exchange in which you are engaged" (Grice, 2004, p. 45). This is how Grice formulates his principle of cooperation between participants in conversations. This can be considered a kind of accord implicitly agreed upon between participants to be tactful to one another in communication (Saeed, 2003). The principle encompasses four maxims that should be abided by in conversations and they are Quality, Quantity, Relevance and Manner. The first is concerned with the amount of information provided in a conversation, the second with the quality of the given information, the third determines that the information should be relevant to the topic discussed and finally, the organization, concision and clarity of the communicated talk is the concern of the fourth (Grice, 2004). In everyday communication, meaning intended is never conveyed directly, which leads to the non-observance of the maxims formulated in the cooperative principle. According to Grice, there are five ways of failure to observe the maxims, flouting, violating, infringing, opting out and suspending a maxim (Thomas, 1995; Waget, 2019). In this study, special attention is given to the analysis of the violation of the four maxims in the main character's conversational contribution.

\subsection{Conversation Analysis and Cinematic Discourse}

Islamic terrorism has been a threat to many countries and Egypt has faced successive waves of Islamic terrorism over the past decades. The assiduous use of force in Egypt was and still is the means of suppressing such waves by security forces. Such waves have continuously been filmed in movies (Allagui \& Najjar, 2011). The ethical and the religious rationalization of the ongoing struggle between the radical Islamic forces and the state was provided by film makers who are publically viewed as guiding the people indirectly yet properly (El Karoui, 2017). The various 
venues media offer enable filmmakers to communicate their ideas effectively and exercise the massive influence which they exert to justify this struggle (Birnbaum, 2013).

The analysis and investigation of structured and orderly talk-in-interaction was originally confined to conversations that occur naturally. For this reason, it has long been advocated as one of the cannons in CA that analysis should be of the natural, spontaneous and unscripted or experimentally induced talk. Many years after that researchers started analyzing different types of talk-in-interaction, for example, institutional talk that occurs in different settings. The different settings are categorized into formal and non-formal (Heritage \& Greatbach, 1991). The formal settings are exemplified in the talk that occurs in institutions such as courts of law, broadcast news interviews or even job interviews and other settings (Sidnell,2010; tenHave,2007). Social work interactions are included in the second type which is the non-formal settings. The talk-ininteraction in these different settings is described as applied conversation analysis as contrasted with what is described as pure conversation analysis which focuses on the natural conversations in our everyday interactions. Although there are attempts by conversation analysis researchers to differentiate between applied and pure conversation analysis, yet there is no fine distinction between the different types of data used experimentally (Chepinchikj \& Thompson, 2016). There have not been clearly identified boundaries between the more or less legitimate data, even though the nature of the data used for CA is somehow controversial. Other means of classifying data is the method of analysis and the setting where this talk-in-interaction takes place (tenHave, 2007; Kozloff, 2000). One major complexity about the analysis of mass media talk, which is considered different from any naturally occurring speech, is that it is not only recorded but planned, practiced and heavily edited. Hence the non-natural feature of this type of discourse. However, people do not shift their interactive techniques in conversations even if the conversation is scripted (Austin, 1962). These conversations are mainly designed to sound natural (ten Have, 2007). Therefore, CA can be applied to these conversations to unfold secrets that are no less important than naturally occurring ones.

\section{Corpus Description and Methodology}

This section includes a description of the theoretical framework utilized and the data chosen in the study.

\subsection{Data Selection \& Rationale}

The study analyzes seven key scenes of the 1994 Egyptian movie Al Irhaby, The Terrorist. This movie is one of the most important movies that sheds light on a dangerous threat that Egypt has faced and still faces till our present times, which is terrorism and radical groups. Ali, the main character, is an Islamic radical member of a radical Islamic group scheming against the government. Ali is portrayed as a middle-aged man who is poorly educated and unemployed. His poor education, poverty, frustration pushed him to join the radical extremist group believing that they will bring reformation and better the lives of many as he was brainwashed to despise, abhor and strive to damage every single thing that is considered against the teachings of Islam as these radicals view it. These things may range from television, thinkers, Christians up to unveiled or uncovered women (Birnbaum, 2013). While escaping from the police after committing one of the terrorist missions, Ali has an accident and stays for a while in a house of an upper middle family to cure him, a stay during which he hides his true identity. During this stay, he alters his beliefs and starts the process of change. By the end of his journey, he abandons his radical beliefs and 
starts viewing people as upright, God fearing individuals who deserve to be appreciated and respected.

\subsection{Analytical Framework}

The selected scenes are analyzed to show the development that takes place in the main character's behavior through analyzing his conversational contribution. This starts by applying the key features of conversation analysis, turn-taking, adjacency pairs, overlaps and gaps. These elements help sketch the fine lines that create the overall picture. Since politeness is a key component in any conversational exchange, Brown and Levinson's Politeness Theory (1987) and in particular the strategies of negative politeness are analyzed in the conversations of the main character. Part and parcel of the analysis of conversations is the analysis of the maxims of the Cooperative Principle (Grice, 2004). In this regard, the focus of this study is only on the violations of the four maxims. Another very important aspect that contributes to the success of human to human communication is eye contact (Rossano, 2013). In accordance with this, the glances of the main character, throughout the selected scenes, are analyzed in terms of the reactional processes as part of the representational meta-function in the theory of Visual Grammar devised by Kress and van Leeuwan (1996). Screen shots taken from the scenes are added to clarify the analysis.

\subsubsection{Conversation Analysis: The Key Elements of Talk-in-Interaction}

This section highlights the key organizational features related to CA, which naturally occur in conversations and are the basis of conversation researchers' work (Lestary, et al., 2017). Any conversation is based on the assumption of having turns exchanged between the participants. Turntalking refers to the change of speakers and this is managed by the speakers themselves, who might select each other or self- select (Liddicoat, 2011). This is why pauses and overlaps take place during conversations or during the selection of the next speaker. Turn-taking organizes the flow of speech between the participants and controls the change in topics to keep the speech continuous. The system of turn-taking is composed of and based on two components, the turn allocational component and the turn constructional component. The turn allocational component is the one that regulates the change-over of turns including speaker selection. The turn constructional component regulates variables like the size or length and linguistic texture of a turn (Hoey, 2017; Sidnell, 2010; Sacks et al., 1974). In this paper, special attention is given to the latter, the turn constructional component.

Another important aspect of talk-in-interaction is adjacency pairs. These are sequences of paired actions. They can occur in the pattern of "question-answer, greeting-greeting, requestgranting offer-acceptance and others (Chepinchikj \& Thompson, 2016). The participants organize their speech according to these adjacency pairs, although, of course not, rigidly abiding by. The characteristics of adjacency pairs are that they are adjacent; they follow one another, are the production of different and not one speaker, and are organized as first pair part (FPP) and second pair part (SPP) (Schegloff \& Sacks, 1973). In this study, the consistency and availability of adjacency pairs are analyzed and commented upon in the selected conversations.

The occurrence of overlaps is another important notion in CA. Overlaps are exemplified in the instances of reduced space in the transition from one speaker to another. They take place right before the transition relevance place (TRP) where the shift happens from one speaker to other speakers. Longer overlaps are quite problematic and are regarded as interruptions which somehow impede communication with the change in the turn order and the number of speakers grabbing the 
floor (Lestary et al., 2017). This will definitely also include hesitations, pauses and selfcorrections (Liddicoat, 2007). In cinematic scripts, many of these features are intended and embedded in the dialogues to convey certain messages and to portray the characters in a certain light. This is the aim of this research paper; to find out how the main character is portrayed through his speech patterns. Despite the arguments of some researchers that cinematic discourse should not be analyzed using CA methods since it is not a naturally occurring speech, many other researchers advocate the usefulness of using such methodology in the analysis of cinematic dialogues which are designed to convey hidden messages that can be uncovered via the analysis (Kozloff, 2000; Richardson, 2010; Rossi, 2011).

Gaps also play a very important role in talk-in-interaction and are considered as a major feature in conversations. Pauses or silences are considered gaps. They represent an enlarged transition space, where no speaker has initiated to take the floor (Hoey, 2017). They either take place within the same turn, intra-turn gaps, or between neighboring turns, inter-turn gaps. If they occur by the end of a turn, they are not associated with any of the speakers. However, if gaps occur before a communicative action is finished, for example after a question, the analysis would reveal much about the recipient. The context in which interactants communicate has a great value in the assessment of the importance of gaps. Lapse in turns or in talk may be a result of a period of silence that may or may not be associated with a particular speaker (Hutchby \& Wooffitt, 2008; Schegloff, 1996). The focus of this study with regard to gaps is the analysis of any problematic silences, whether long or short and which may result in turn lapses, which occur on the part of the main character.

\subsubsection{Cooperative Principle}

In conversations, speakers and hearers rarely abide by the rules of the Cooperative Principle. When speakers voluntarily choose not to abide by any of the maxims, this is when violations occur (Grice, 2004). These violations are done with the aim of deceiving and causing misunderstandings on the hearers' part and they take place when speakers intentionally refrain to apply certain maxims in their conversation (Waget, 2019). If more than one maxim is violated at the same time, an incident of a multiple violation takes place. Violations of the maxim of quantity occur when the speaker fails to abide by offering the adequate information needed. When speakers provide information which is not true, they violate the maxim of quality which is highly related to the speakers' honesty to provide correct information to their hearers. If the conversational contribution of the speakers is irrelevant to the topic discussed, the speakers in this case violate the maxim of relation. Speakers not only have to be relevant when they provide information or respond, they also have to avoid being ambiguous. The obscurity of expression, being redundant and the irrelevant prolixity is what speakers do when they violate the maxim or manner (Grice, 2004). In almost all conversations, speakers rarely strictly abide by the maxims as described by Grice.

\subsubsection{Politeness Theory}

According to Brown and Levinson (1987) when face threatening acts (FTAs) are unavoidable, speakers can redress the threat with negative politeness that respects the hearer's negative face, the need to be independent and have freedom of action. They can also redress the face threatening acts (FTAs) with positive politeness that attends to the positive face, the need to be accepted by others (Cutting, 2002). 
In this study, the focus is on analyzing the negative politeness strategies, in accordance with Brown and Levinson (1987), as employed by the main character throughout his conversational exchange with the other characters. Negative politeness expresses the desire of the speakers to mitigate imposition on the hearers' part. There are generally a number of negative politeness strategies, be conventionally indirect in your talk, use questions and hedging, be pessimistic or rather structure your turns as though you expect refusal, minimize imposition, show and give deference, give apologies, impersonalize speaker and hearer through avoiding the firstand second-person pronouns, go on record and use nominalizations (Eshreteh \& Draweesh, 2018). Once proven evident in the turns of the main character, these strategies are analyzed and commented upon.

\subsubsection{The Representational Metafunction}

The representational meta-function includes five types of narrative processes which encode different relations between the participants. The encoding of the glances of the participants takes place through the reactional processes. Through this multimodal dimension, reactions are encoded through the direction of the glances of the participants through an imaginary line called vector which indicates directionality; the vector is formed by the direction of the glance (Kress \& van Leeuwen, 2006, pp. 67). Similar to the action processes, the reactional process can either be transactional or non-transactional. It is transactional if the glance of the reactor is directed towards another participant, described as the phenomenon (Hu \& Luo, 2016). It is non-transactional if the glance of the reactor is directed to the outside or to something outside the picture frame, towards the viewer or an imaginary participant. Since the glances contribute to the success or failure of any communicative exchange (Planck, 2013; Ruusuvuori \& Peräkylä, 2009), the glances of the main character are analyzed to show his relation with the other characters.

\section{Analysis and Results}

The data chosen for this study make a total of seven key scenes in the movie. These scenes show three waves in the main character's behavior and beliefs. Two of these scenes are considered the opening ones in the movie, where the main character, Ali A. Thaher, is having conversations with the leader of the brotherhood or the prince of the radical Islamic group. These two scenes mark the relationship Ali, the main character, has with the leader of the terrorist group he belongs to. They also show the beliefs and ideas, which they are brain washed to believe in and fight for. The third scene is his first encounter with the upper middle-class family he is going to stay with for some time; a stay which will be the reason behind the change in his behavior. The fourth is the scene when Ali meets one of the family's friends, a journalist called Dr. Fouad Massoud, who is considered an enemy to Ali's radical group. The scene that follows is one that marks the change in the main character's behavior, where he gets to discuss his feelings and thoughts, a taboo for radicals of course. The sixth scene is the confrontation scene with the family on the day he decides to leave their house and discover his true identity. The last scene is a confrontation with the terrorist group and its leader, which marks the final and most outstanding change in the conversational behavior of Ali A. Thaher leading to his death at the hands of those whom he used to belong to and believe in.

The analysis starts with a description of each scene. This is followed by the analysis of the scenes employing the key features of conversation analysis, the violations of the maxims, the strategies of negative politeness and finally the analysis of the glances. This is done to trace the development that takes place in the character through his conversational contributions. 


\subsection{Scene 1: Celebrating a Mission}

This is the first scene in the movie where the characters start a conversation. The characters in this scene are Ali, the main character (the terrorist), and his leader prince Seif or brother Seif as Ali calls him throughout. This meeting follows the mission that Ali and his group members have just finished. Ali appears as heavy hearted and Seif asks him what the matter is. This conversation makes up a total of ten turns distributed evenly between the two speakers, Seif and Aly. The first four turns show clear adjacency pairs of question and answer between the two speakers, where Seif occupies the FPP and Ali the SPP.

Seif (1): What's wrong brother Ali?

Ali (2): Days pass and people are as corrupt and lost as they are

Seif (3): Be patient brother Ali

Ali (4): till when? I had quit my job and joined the brotherhood for our Islamic revolution and I am unemployed for years now.

Here, Ali's turns are marked as long ones and the conversation sounds as a normal discussion between the two participants; a pattern which is interrupted quickly to set the tone of the relationship between Ali, a member in the radical group, and his leader. Dissatisfied with his response and attempt to express his thoughts, Seif interrupts Ali to show dominance and control over him in a face threatening act (FTA) saying, "Don't argue Ali. This is a very dangerous matter. "Hesitation marks occur in Ali's response as a mark of fear to upset his leader as the former tries to re-express his thoughts saying "I only meant...." Seif grabs the floor, interrupts Ali and changes the topic ordering Ali not to argue and then later asking Ali to pay him a visit to discuss an important matter. Ali could not grab the floor again, but only responded conforming to Seif, "You are our prince and we must obey you". Ali's turns are all declarative statements as he was only trying to express his ideas, a taboo for radical Islamic group members. Being so direct and obedient to his leader, there is no record of violation of any of the maxims of the cooperative principle.

Ali employs negative politeness strategies in showing deference to his leader. This is clear when he was interrupted by Seif and tried to re-express his point of view, not in the form of disagreement but rather in the form of explanation, as he says, "I only meant...". This is followed by the statement which he was dictated as a doctrine, "You are our prince and we must obey you". The terms of address clearly show the social distance between the speakers. Ali calls Seif "brother Seif' or 'our prince' to show belonging and respect especially with the use of the plural possessive personal pronoun 'our' while the latter uses only the first name, Ali, to address him. Here, it is worth mentioning that Ali employs the strategy of using solidarity and in-group identity markers or in-group slang as he uses the term brother or prince (Eshreteh \& Draweesh, 2018).

Reactional processes are concerned with the analysis of the direction of the glances of the reactor; a very important aspect which plays a huge role in the success or failure of communication. Ali's glances are directed either to the nowhere or directed downwards in humility. He does not direct his glances towards the prince, the only other participant in the conversation. This is intended to show respect and owe and is an evidence of non-transactional reactional processes. No direct contact was built between the two participants in this scene and this is intended to show the huge 
gap between the two speakers and also to establish the mood of their relationship as shown in figures 1 and 2 .

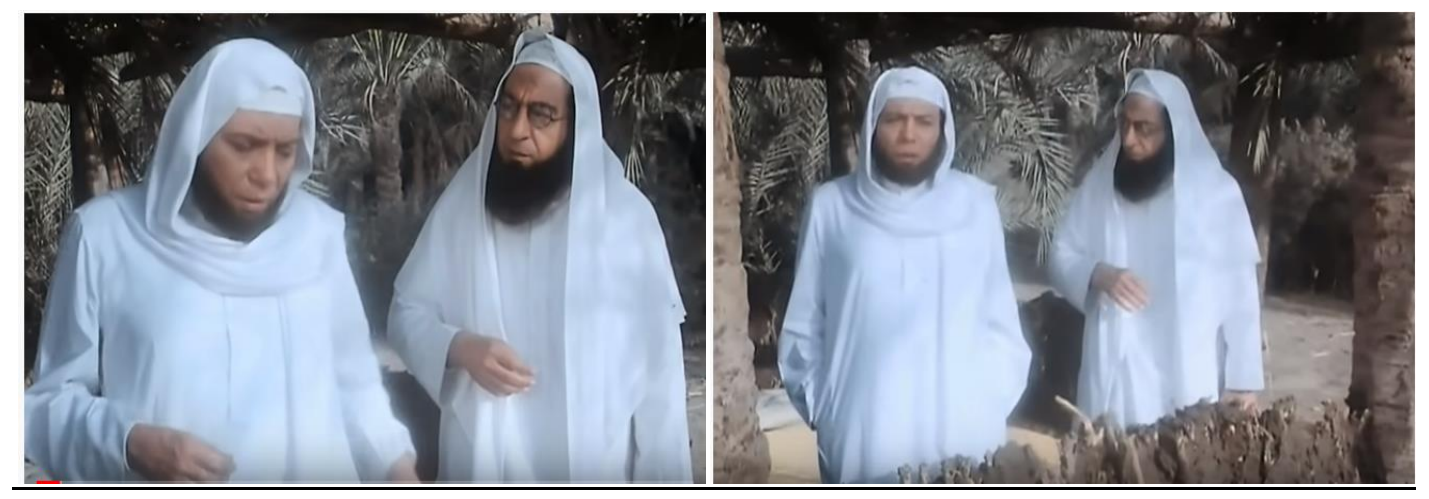

Figure 1

Figure 2

\subsection{Scene 2: The Bribe}

This scene comes next having the same speakers as in the first scene, Ali and Seif, as the dominant participants and a third speaker, Rasheda, with minimal conversational contribution. Rasheda, Ali's newly suggested bride, has only two turns in the whole conversation. The conversation makes a total of 16 turns. The situation is more of a bribe to Ali to go on a new terrorist mission to assassinate a police officer. Seif summons Ali to his house to inform him that he has chosen a wife for him; a sister of one of the former's wives whom he has divorced her from her husband who works for the atheist government.

Ali is portrayed as an ill-educated poor man, a perfect target for the radical Islamic groups. He occupies seven of the 16 turns, which are mostly questions as he is eager to know about the bride and the details of the awaited wedding, an opportunity which he can't afford to miss, "And where can I find such bride?", "And when is the wedding by Allah's will grace?" and "Is she divorced?"

All these turns show that he is a follower to Seif. Only two of his seven turns are declarative statements where he mentions that he has no money to buy his bride a gift and the other where he repeats, "You are our prince and we must obey you", a creed of the Islamic groups. No overlaps take place, since Ali can never interrupt his leader to change the topic or grab the floor. He seeks information and has no right to argue or mention a contrary point of view. At this stage, there is no violation of the maxims.

In his first conversational turn, Ali responds to Seif's decision that he has chosen him a wife in a question. This question shows Ali's rejection of the idea in an indirect speech act as he uses a question instead of a declarative statement to state that he can't afford to get married as he does have neither money nor a house saying "Brother Seif, how can I get married if I don't own a house of my own?" This is an employment of negative politeness where he shows disagreement indirectly to show deference to his addressee.

In this scene, the reactional processes are all transactional; Ali either looks to Seif in eagerness to know about the bride or to Rasheda, who is fully covered in Niqab, in a quick glance to check her as shown in figures 3 and 4 respectively. 


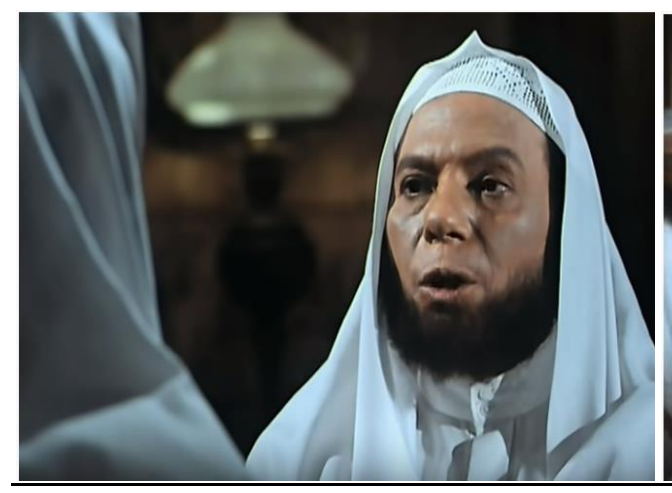

Figure 3

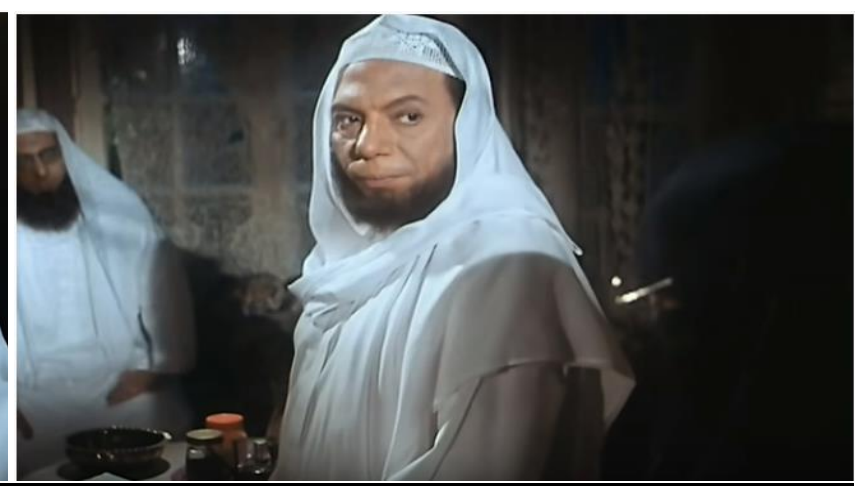

Figure 4

\subsection{Scene 3: Meeting the Family}

The scene is an introduction to the family members who have mistaken Ali to be another person; a professor of Philosophy; a false identity Ali adopts during his stay with the family. Ali has stolen his car to cover for a mission before being hit by Sawasan's car. They opened a suitcase that Ali stole to hide his gun and found Dr. Mustafa A. Rahman's personal notebook. The scene makes a total of 41 turns distributed amongst six characters, Ali, Dr. A. Moneim (the father), Thoraya (the mother), Mohsen (the elder son), Sawsan (the elder daughter) and Faten (the youngest daughter). Of these 41 turns, Ali occupies 14.

The regular adjacency pairs that used to exist in his conversations with his leader have disappeared. He starts his turns in two questions after waking up to find that he has broken his leg, Where am I? Who are you? as an answer to Dr. A. Moneim, who was checking how he feels. When Sawsan apologizes to him for being the reason behind the accident, he repeats the question, Who are you? instead of a proper response to her apology. His following turns lapse as he refuses to grab the floor and greet the members of the family who are introducing themselves and greeting him. The sequences of adjacency pairs are mostly missing in Ali's speech, except in the second half of his turns where he starts finding out about the false identity they believe he holds. Pauses and hesitation marks appear in his speech as he lies about his identity and is confused. For example, when addressed as Mr. Mustafa, he asks, "Who is Mustafa?" and "Mustafa, yes, Mustafa" and in another turn, "Mustafa A. Rahman, yes, Mustafa A. Rahman". The same happens when they tell him that he is a professor of philosophy and he responds, "philosophy, yes, philosophy". Repetitions and pauses occur on Ali's part showing his confusion and fear of having his identity discovered. It is his means to convince them that he is the person they think he is.

A disfluency mark showing poor education occurs as he responds to the doctor's speculation for forgetting his name that he suffers from concussion; a word that he mispronounces and says, "Yes, I feel that my brain is shaking". Towards the end of the conversation, he deliberately lets his turns lapse with no desire to communicate any further.

In this scene, multiple violations take place. When Dr. A. Moneim greets Ali after he wakes up and welcomes him, the latter violates the maxim of relation in a question asking him who he is. The same happens when Sawsan apologizes to him for having been the reason behind his injury. The same is repeated with the other family members introducing themselves to him and he ignores them by asking about what happened. Most of the violations of the maxim of relation, on Ali's part, take the interrogative form, because he wants to understand what has happened to be able to 
assess the situation and prepare to escape. When the doctor explains that he broke his leg, Ali violates again the maxim of relation and asks if they have reported the incident to the police. When they offer, if he wishes, to report to the police, he then violates the maxim of quality by lying through rejecting as he forgives them. Violations of the maxim of quality are repeated in this scene as he starts lying about his identity.

In this scene, there is no evidence of using negative politeness strategies. His aim is not to be accepted by the speakers, but rather to hide his identity from them.

Successful communication in conversations is partly determined by the exchange of glances (Planck, 2013). Ali's glances in this scene are mostly transactional as he looks to the family members. The glances are accompanied by facial expressions of despise and anger reflecting how he feels as shown in figure 5 .

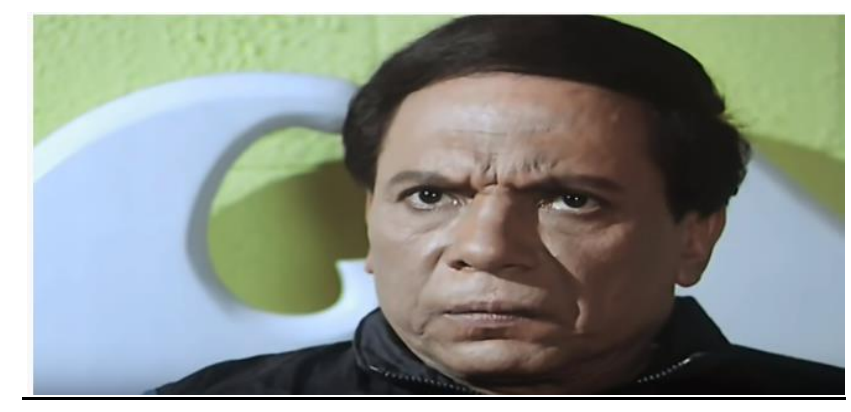

Figure 5

\subsection{Scene 4: Meeting Fouad Massoud}

In this scene, Fouad Massoud, a journalist and family friend, comes for a visit. He is supposed to be the radicals' next victim and Ali was the one eager to avenge the radical group and assassinate him as he attacks them in all his writings.

This conversation makes up a total of 22 turns distributed amongst six speakers, four of the family members, Ali and Dr. Fouad. Of the 22 turns, seven are conversational contributions of Ali. They start discussing the possibility that these terrorists might take over Egypt one day. Dr. Fouad rejects the idea saying that Egypt will never be led by these uncivilized groups. Ali grabs the floor to terrify him and mentions that these groups threaten Dr. Fouad's life saying "but I heard they threatened you and that you are their next target." Ali feels that he is powerful and stands on firm grounds and is defending Islam. These beliefs gave him the strength to grab the floor more than once, self-select and initiate a topic or even change it.

Ali grabs the floor again and asks Dr. Fouad, "Do you carry a weapon?" after Dr. Fouad mentions that he will definitely defend himself, with the latter bringing a pen out of his pocket confirming that his pen is mightier than a sword and asks "What is the devil afraid of?" and Ali immediately grabs the floor and responds, "of worshiping God", but fails to do the same with the next question Dr. Fouad asks, "How about the ignorant?" and Dr. A. Moneim responds, "of knowledge of course"; an answer that Ali is never able to provide and the turn lapses, but finally succeeds to grab the floor again to sarcastically respond to Dr. Fouad who says that he will never flee his country to save his life saying "oh, you are so brave". The last turn Ali contributes is a FTA by calling Dr. Fouad an atheist after the former recites the Quran. Ali says, "but you are an atheist" which he mitigates after a pause noticing the shock in everyone's looks with all glances 
directed to him "I mean in their opinion" that is the terrorists. Adjacency pairs are quite evident in all Ali's turns that come in response to Dr. Fouad's. He is defending his beliefs and ideas and wants to prove that they are legit. The address terms are also worth mentioning here since Dr. Fouad uses Mr. Mustafa and Ali refuses to use any address terms except 'you' which in Arabic shows disrespect, especially that they are strangers and honorifics are always preferred.

In this scene, there is no evidence of the violation of the maxims. There is also no evidence of the employment of any of the negative politeness strategies in this scene; only the FTAs committed on Ali's part.

All the reactional processes in this scene are transactional, where Ali fiercely directs his glances to Dr. Fouad, an enemy of the radical group. This is accompanied by facial expressions of hatred and despise as shown in figure 6. The scene ends with looks of confusion on Ali's face after Dr. Fouad recites the Quran. Ali and his companions are brain-washed to believe that they are the only believers.

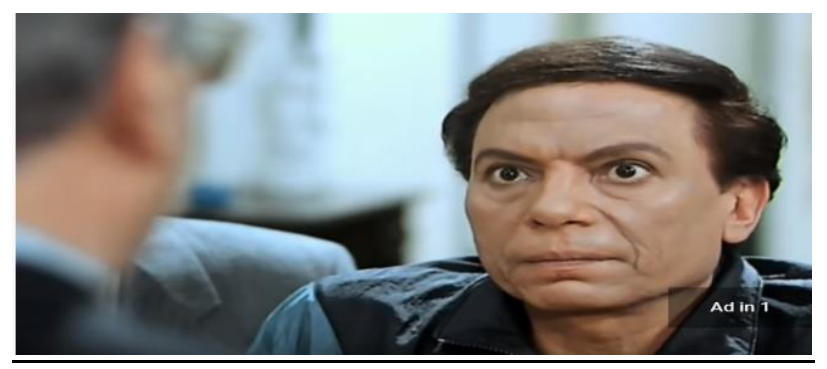

Figure 6

\subsection{Scene 5: The Change}

This scene marks the stage where Ali starts changing. The change starts happening when he falls in love with the family's elder daughter. Ali asks Mohsen questions about the girl the latter loves and how he feels when they meet, trying to find information on a topic or rather a feeling that he has never experienced before and never confessed since, according to the teachings of the group he belonged to, it is a taboo.

This conversation makes a total of 12 turns divided evenly between the two speakers, Ali and Mohsen. This is the first scene where Ali's conversational contributions are distributed evenly with other participants. No overlaps or hesitation marks or pauses are evident. This is a natural conversation between two friends. Most of his turns are questions; he asks eagerly about a topic he was never given the space to discuss.

Ali violates the maxim of quality as he lies about the feelings he has towards Mohsen's sister. He lies as he responds to Mohsen's question "What is wrong with you?" that instead of confessing that he has feelings for his sister, answers "I am just chatting."

In this scene, Ali employs negative politeness strategies of hedging and being indirect. This takes place when he asks the questions about feelings he experiences and asks Mohsen about his feelings when he meets his girlfriend, "what do you say when you meet? don't you experience beautiful feelings", and also when he says, "how did you know that you love her?" 
This scene marks the change in Ali's behavior. Now, he speaks his mind and expresses his feelings. As shown in figure 7, the reactional processes are transactional and accompanied by a relaxed face, a friendly look and a smile.

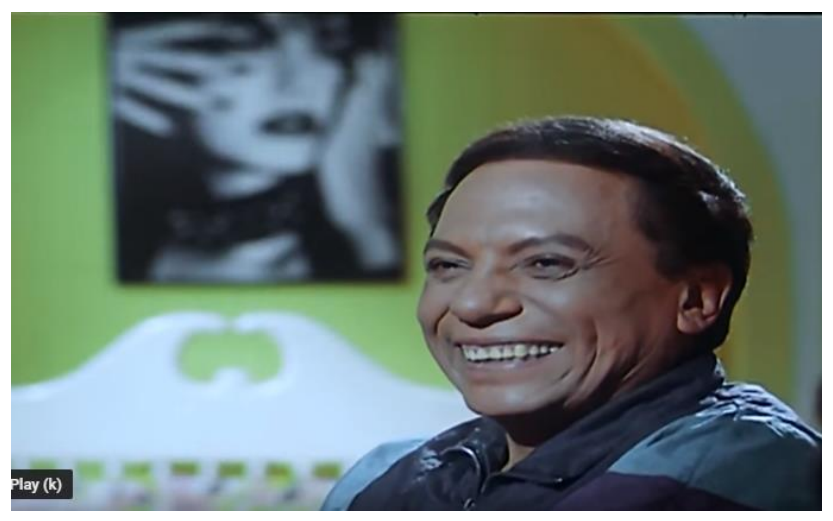

Figure 7

\subsection{Scene 6: The Family Confrontation}

This scene takes place towards the end of the movie as Ali decides to leave the house. It is a master scene, where a confrontation takes place between the family members and Ali as they get to discover his true identity. This scene is considered more of a confrontation of the radical ideas and beliefs of Ali with the moderate ideas and beliefs of others. In this conversation, Ali tries to defend his radical ideas and witness them clash with the moderate and peaceful ideas of the family.

The conversation makes a total of 48 turns distributed between six speakers, of which Ali occupies 14. The linguistic texture of his turns is divided into two parts. The first part is made up of friendly messages of farewell and expressions of appreciation to the family and the other part which makes about six turns is divided between hesitations and repetitions and a weak trial to defend his old beliefs. The normal adjacency pair pattern has started featuring in the main character's conversational behavior after having changed as a person who can engage in normal conversations. Ali thanks Mohsen for his generosity saying "You have a pure heart Mohsen; you only need to pray." Now, Ali understands and accepts people and advises them in a mild tone. The friendly conversation soon ends when the youngest daughter reveals the true identity. This is when the confrontation begins.

In this part, Ali lets his turn lapse more than once; when Faten asks him to inform them of his true identity and second, when she addresses him again to say who he really is. A third lapse takes place after the doctor asks him if what Faten says is true and a fourth after the mother asks him why he keeps his silence. He then starts responding when the doctor addresses him again saying, "I think it is our right to know you true name at least." In his first response, Ali contributes a turn that is made up of questions "What good would my name do to you? What difference would it make?" Turn lapses take place again when confronted by Faten who asks him about the car he stole and the gun he keeps. Ali, then, contributes a turn made up of only the first person pronoun $I$ repeated twice in hesitation "I ... I...." This shows his hesitation to mention who he really is. He then has the courage to mention his identity after Faten threatens to call the police saying, "Yes, I am who you call a terrorist because I terrorize God's enemies". There is no evidence of violations of any of the maxims. He used the 
negative politeness strategy of being apologetic in "I am sorry for last night" apologizing for the inconvenience he caused in the party.

The glances, throughout, are all transactional as shown in figure 8.

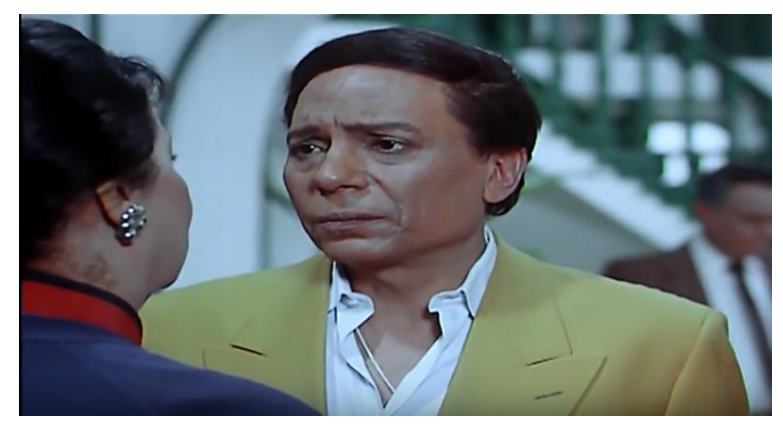

Figure 8

\subsection{Scene 7: Confrontation with the Radicals}

This scene marks another master scene in the movie, where a confrontation takes place between Ali and the radical group members, who are sure that he is not one of them anymore. He has returned to show a different personality, which is reflected in the change that has taken place in his conversational behavior. This conversation comprises 25 turns distributed amongst four speakers, Ali occupies twelve, Seif, eight, a member of the group three and finally a contribution of two turns by Brother Shaalan.

Adjacency pairs are strictly abided by; Ali abides by to express his thoughts at length. It is at this point, that he is capable of running a normal conversation and argues to express his ideas. He sounds more powerful as longer turns are managed to show that he got rid of the fear even when threatened not to argue as he refuses to go on a mission with them saying I served you for many years and I deserve to rest and also rejects the bride offered to him for marriage and says $I$ don't want to marry now. He keeps the same address term brother whenever he addresses them. The topics initiated in this conversation are all managed on the part of the other participants but he managed to keep his turns and express himself quite well. The glances in this scene are all transactional looking directly to all his addresses.

\section{Discussion \& Conclusion}

The analysis of the movie key scenes is done through using the conversation analysis tools, Grice maxims, the theory of politeness and the analysis of the glances, which contribute a great deal to the success of conversations. The aim of this study is to investigate the change in the main character's behavior through the analysis of his conversational contribution. At the beginning, adjacency pairs are evident in Ali's conversations with his leader. These pairs are filled with pauses and marks of hesitation and the absence of the initiative to grab the floor or change topics. The turns are remarkably short and are filled with repetitious statements that show conformity to his leader prince. The address terms that show respect and owe are always employed accompanied by showing deference as a strategy and the use of in-group slang and the plural personal pronoun confirming the need to belong, strategies that were absent in the conversations with the family members. Multiple violations of the maxims started appearing with his encounter with the family and his need to hide his true identity. The patterns of adjacency pairs disappeared with more turn lapses showing the lack of desire to communicate. This changed with the development that started 
happening to him. The pattern of adjacency pairs followed a certain track; maintaining them to conform to the leader and respond to his questions, disappearing with the family encounters, reappearing to express thoughts both with the family and the radicals in the end. The direction of the glances also showed change over the stages of development; non-transactional patterns to transactional accompanied by looks of hatred and anger to transactional accompanied with friendly and relaxed looks. Successful conversations were achieved after this pattern of the reactional processes occurred.

The framework adopted helped trace the change that has taken place in the character's behavior. Conversation analysis tools uncovered the character which started as a follower incapable of expressing ideas brainwashed to consider it a taboo. Committing multiple violations of the maxims to deceive and employing negative politeness strategies or refraining from employing them contributed with the analysis of the glances to portray the character even closely. 


\section{References}

Allagui, I., \& Najjar, A. (2011). Framing Political Islam in Popular Egyptian Cinema. Middle East Journal of Culture and Communication, 4(2), 203-244. https://doi.org/10.1163/187398611X571373.

Austin, J.L. (1962). How to Do Things with Words: The William James Lectures Delivered at Harvard University in 1955. Urmson, J.O., (Ed.). Clarendon Press, Oxford.

Aydinoglu, N. (2013). Politeness and Impoliteness Strategies: An Analysis of Gender Differences in Geranyl Horton's plays. Procedia -Social and Behavioral Sciences, 83, 473 -482.

Birnbaum, S. (2013) Egyptian Cinema as a Tool in the Struggle Against Islamic Terrorism. Terrorism and Political Violence, 25:4, 635-639, DOI: 10.1080/09546553.2013.814505

Brown, P., \& Levinson, S. (1978), Universals in Language Usage: Politeness Phenomena. In E. N. Goody (Ed.), Questions and Politeness: Strategies in Social Interaction, 56-289. Cambridge: Cambridge University Press.

Brown, P., \& Levinson, S. (1987) Politeness: Some Universals in Language Usage. Cambridge University Press, Cambridge,

Chepinchikj, N. \& Thompson, C. (2016). Analysing Cinematic Discourse Using Conversation Analysis. Discourse, Context \& Media. 14. 10.1016/j.dcm.2016.09.001.

Cutting, J. (2002). Pragmatics and Discourse: A Resource Bookfor Students. London: Routledge.

El Karoui, D. (2017). Deciphering the Binary Code "Egyptian versus Foreigner" in Egyptian Cinema. Journal of Arabic and Islamic Studies, 16, 368-384. https://doi.org/10.5617/jais.4757

Emmison, M. (1993) On the Analyzability of Conversational Fabrication: A Conceptual Inquiry and Single Case Example. Australian Review of Applied Linguistics 16, 83-108.

Eshreteh, M. \& Draweesh, Y. (2018). Applying Brown and Levinson's Politeness Theory on Lady Macbeth's Speech in Shakespeare's Macbeth. Applied Linguistics Research Journal, 2(1), April 2018.

Grice, H. P. (2004). Logic and Conversation. Berkeley: University of California.

Goffman, E. (1972). On Face-Work: An Analysis of Ritual Elements in Social Interaction. In Interaction Ritual: Essays on Face to-Face Behaviour, ed. E. Goffman, 5-46. London: The Penguin Press.

Heritage, J. \& Greatbatch, D. (1991). On the Institutional Character of Institutional Talk: The Case of News Interviews. In Dierdre Boden and Don H Zimmerman (ed.) Talk and Social Structure. Berkeley: University of California Press, pp. 93-137.

Hoey, E. M. \& Kendrick, K. H. (2017). Conversation Analysis. In A. M. B. de Groot \& P. Hagoort (eds.), Research Methods in Psycholinguistics: A Practical Guide. U.K: Wiley Blackwell.

Hu, C.\& Luo, M. (2016). A Multimodal Discourse Analysis of Tmall's Double Eleven Advertisement. Journal of English Language Teaching. 9 (8), 156-169. 
Hutchby, I. \&Wooffitt, R., (2008). Conversation Analysis, $2^{\text {nd }}$ ed. Polity Press, Cambridge, Malden, MA.

Kozloff, S. (2000). Overhearing Film Dialogue. Los Angeles: University of California Press.

Kress, G.\& van Leeuwen, T. (2006). Reading Images: The Grammar of Visual Design (2 ${ }^{\text {nd }}$ ed.). London: Routledge.

Lestary, A., Krismanti, N. \& Hermaniar, Y. (2017) Interruptions and Silences in Conversations: A Turn-Taking Analysis. Journal of Linguistics and Education, 7 (2), 53-64.

Liddicoat, A. J., (2007). An Introduction to Conversation Analysis. Great Britain: Athenaeum Press Ltd.

Piazza, R., Bednarek, M. \& Rossi, F. (Eds.) (2011). Telecinematic Discourse: Approaches to the Language of Films and Television Series. London/New York: Routledge.

Planck, M. (2013). The Handbook of Conversation Analysis, First Edition. Sidnell, J., Stivers, T. (Eds.) Blackwell Publishing Ltd.

Richardson, K. (2010). Television Dramatic Dialogue: A Sociolinguistic Study. New York: Oxford University Press.

Rossano, F. (2013), Gaze in Conversation. In The Handbook of Conversation Analysis (Jack Sidnell, Tanya Stivers, eds., Oxford, U.K: Wiley-Blackwell, pp. 308-329.

Rossi, F. (2011) Discourse Analysis of Film Dialogues: Italian Comedy between Linguistic Realism and Pragmatic Non-realism. In: Piazza, R., Bednarek, M., Rossi, F. (Eds.), Telecinematic Discourse: Approaches to the Language of Films and Television Series. John Benjamin’s Publishing Company, Amsterdam, Philadelphia, pp. 21-46.

Ruusuvuori, J., Peräkylä, A. (2009) Facial and Verbal Expressions in Assessing Stories and Topics, Research on Language and Social Interaction ,42(4), pp. 377- 394 . URL http://hdl.handle.net/10138/29481.

Sacks, H., Schegloff, E.A. \& Jefferson, G., (1974). A Simplest Systematics for the Organization of Turn-taking for Conversation. Language 50(4), 696-735.

Saeed, J. I. (2003). Semantics (Second ed.). Malden, MA: Blackwell Publishing Ltd.

Schegloff, E.A. \& Sacks, H. (1973). Opening up closings. Semiotic 7, 289-327.

Schegloff, E.A. (1996) Turn Organization: One Intersection of Grammar and Interaction. In: Ochs, E., Schegloff, E.A. Thompson, S.A.(Eds.),Interaction and Grammar. Cambridge: Cambridge University Press, pp.52-133.

Sidnell, J. (2010). Conversation analysis: An introduction. Chichester, U.K: Wiley-Blackwell. ten Have, P. (2007). Doing Conversation Analysis: A Practical Guide, $2^{\text {nd }}$ ed. London: Sage. Thomas, J. (1995). Meaning in interaction: An Introduction to Pragmatics. London: Longman.

Waget, A. (2019). Violations of Grice`s Maxims in The Prince and the Pauper Movie. LLT Journal, 18 (1), 1-10. DOI: https://doi.org/10.24071/llt.2015.180101. 
https://bok.cc/s/?q=Egyptian+Cinema+as+a+Tool+in+the+Struggle+Against+Islamic+Terrorism + Sariel+Birnbaum

https://www.egypttoday.com/Article/4/29134/Terrorism-Islamic-extremism-portrayed-byEgyptian-cinema-part-1 